\title{
RUPERT
}

The following story comes to us from the Wild Life Preservation Society of Southern Rhodesia.

One of the animals rescued by Operation Noah from an island in Kariba lake when Kariba dam flooded the Zambezi valley was a baby black rhinoceros.

In May, 1962, a female rhinoceros, immobilized by a drug so that she could be taken from a flooded island to the Wankie National Park, fell whilst crossing a stretch of shallow water and was drowned. Her calf was easily captured and it was decided to attempt to rear him by hand. Accordingly he, together with a pint of milk taken from the dead mother, was transported 250 miles to Salisbury. There a government veterinary surgeon and his wife took charge of him, naming him "Rupert" after Rupert Fothergill of Operation Noah fame.

The May nights in Salisbury at 5,000 feet were terribly cold compared with the Zambezi valley, so his foster-parents adapted a corner of their garage as night quarters, with bales of hay to line the walls, thick litter on the floor, and a battery of infra-red lamps to give artificial heat.

In the meantime, the mother rhino's milk had been analyzed, and bottle feeding of the little orphan started using a calf teat on sterilized soft-drink bottles. The number of feeds at the outset was six, of one pint each, later being increased to four feeds of six pints each.

The change from natural to artificial milk, and a curious habit of eartheating in the early days caused serious constipation, so that an enema had to be administered on the tenth day. This worked, and with the exception of two attacks of diarrhoea in June, which were cured by charcoal and a starvation diet, Rupert thrived and grew into a really healthy young animal. Later on he took his milk from a bucket, sucking it from the teat via a plastic tube, whose bottom end was immersed in the liquid, which saved an immense amount of work with the bottles, as can be imagined. He put on weight steadily, from his initial $150 \mathrm{lbs}$. in the middle of May to $260 \mathrm{lbs}$. in August, when he became too wide for the cage of the pig scales which had been used to weigh him. After that no further readings could be taken until his journey to the Matopos National Park when the public weighbridge in Bulawayo showed him to be $530 \mathrm{lbs}$. His shoulder height (withers) on arrival in May was 27 inches, in July 30 inches, in August 33 inches, in September 36 inches, and at departure on 5th November 40 inches. Other dimensions on leaving were : length of head 16 inches, length of body 46 inches, length of tail 18 inches, front horn 3 inches, heart girth 60 inches and maximum girth (round belly) 62 inches.

Rupert's health was excellent, and he always appeared to be in perfect condition, with no sores, growths or deformities of any kind, a tribute to the skilled professional care of his foster parents. He soon adopted the normal rhino habit of defecating at one fixed spot, and chose for this purpose a small asbestos hut. He also got into the way of kicking dung about with his hind legs, a remarkable example of a hereditary habit being adopted with the minimum of parental instruction.

Rupert started browsing leaves from shrubs and trees from the age of 

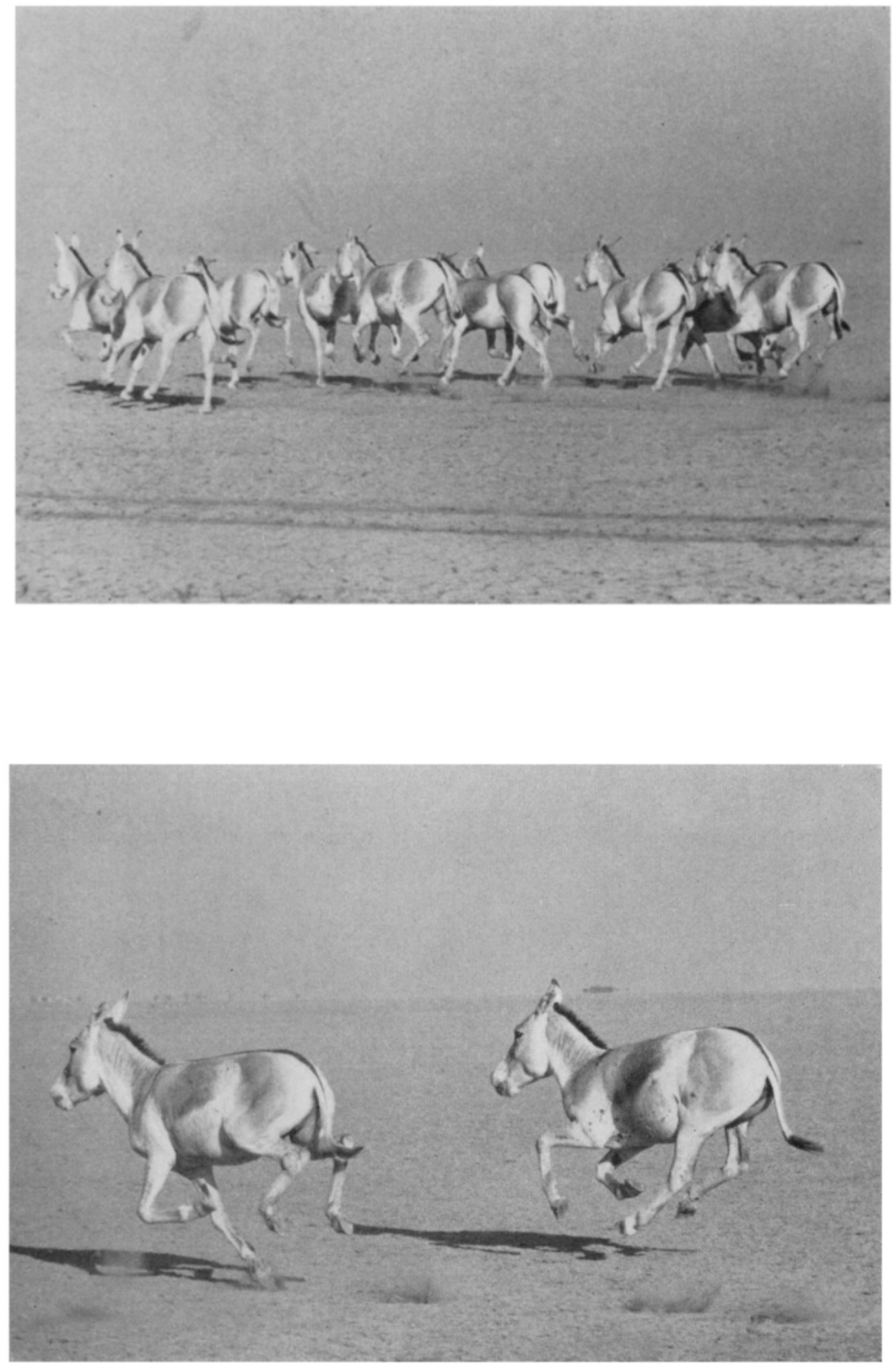

Photos ; E. P. Gee.

\section{THE INDIAN WILD ASS}




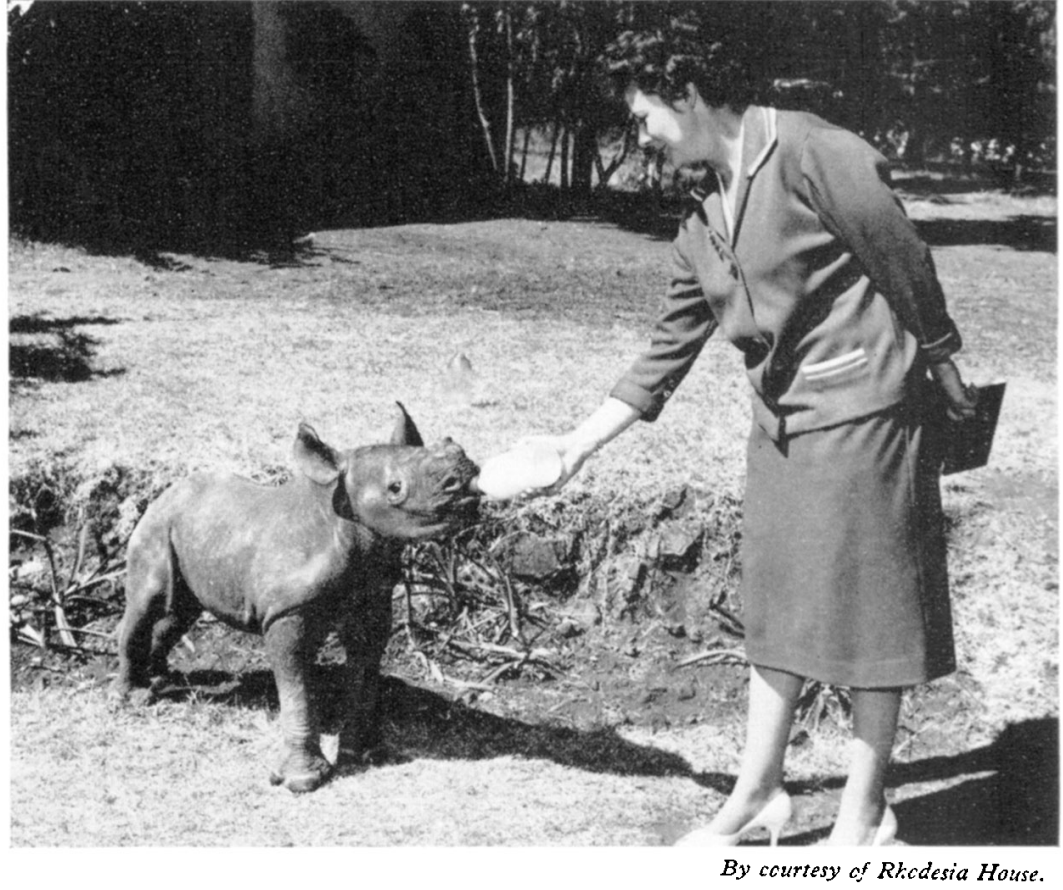

RUPERT, RESCUED FROM THE KARIBA FLOODS. ABOUT 6 WEEKS OLD. MAY, 1962.

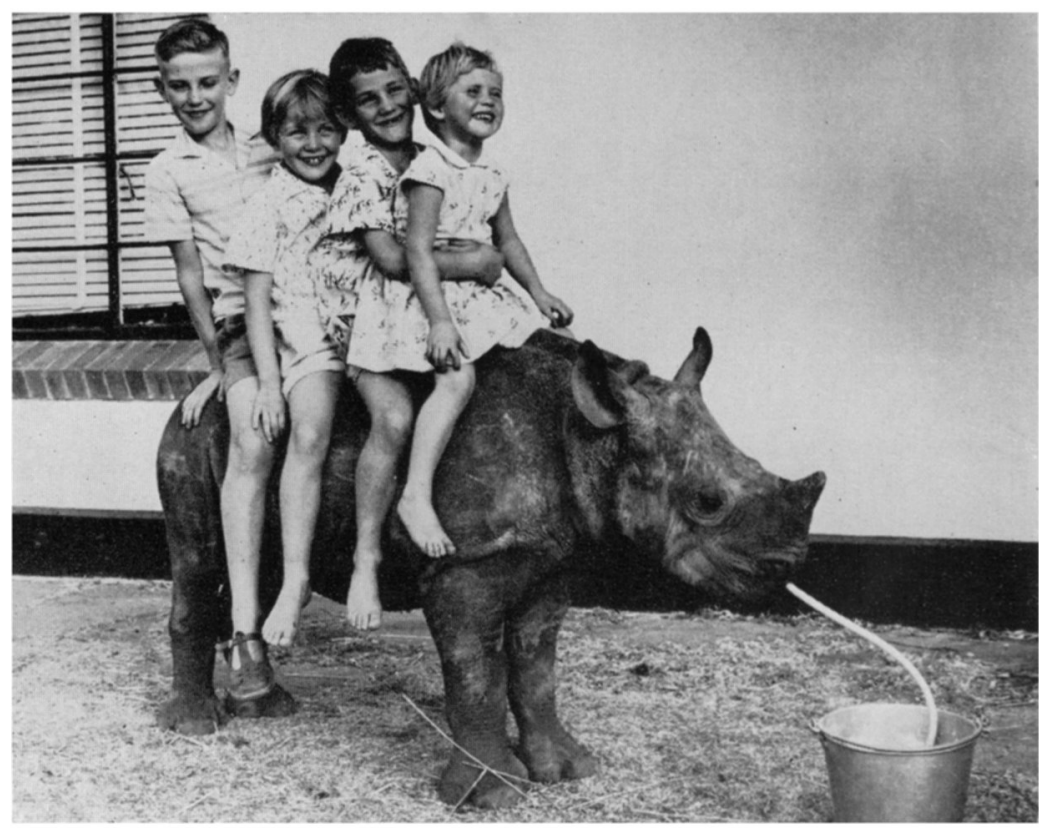

By courtesy of Rhodesia House.

RUPERT, NOW 6 TO 7 MONTHS OLD. OCTOBER, 1962. 


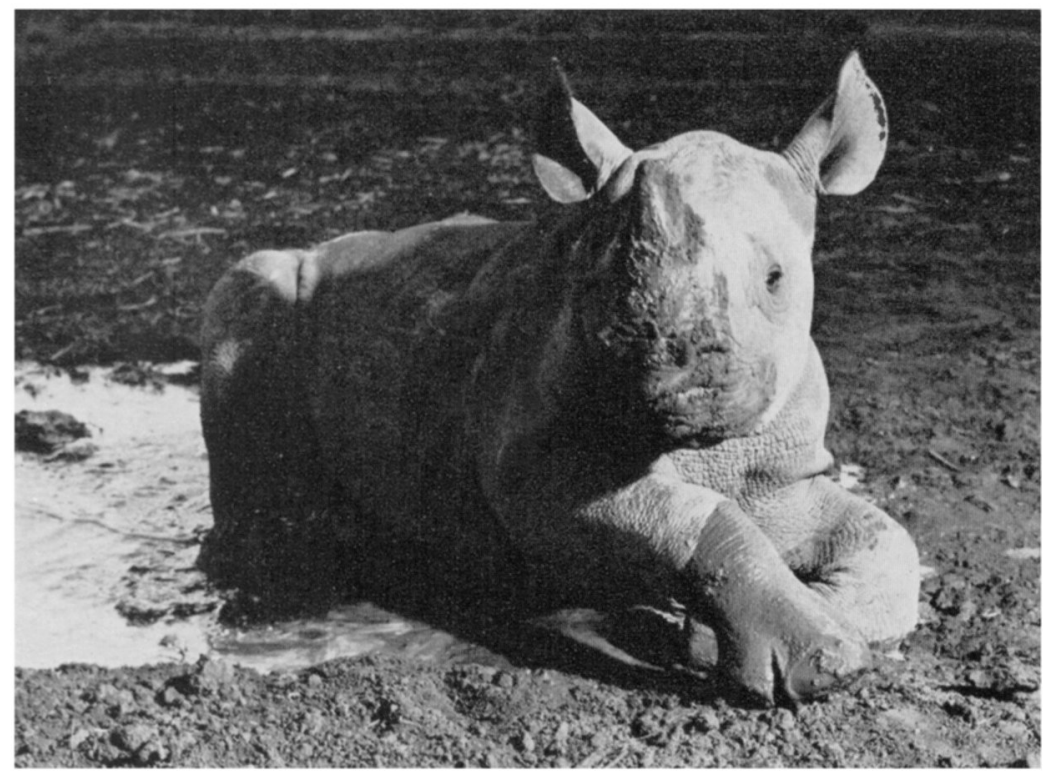

By courtesy of Rhodesia House.

RUPERT, 7 MONTHS OLD, AT THE END OF DOMESTICITY. OCTOBER, 1962.

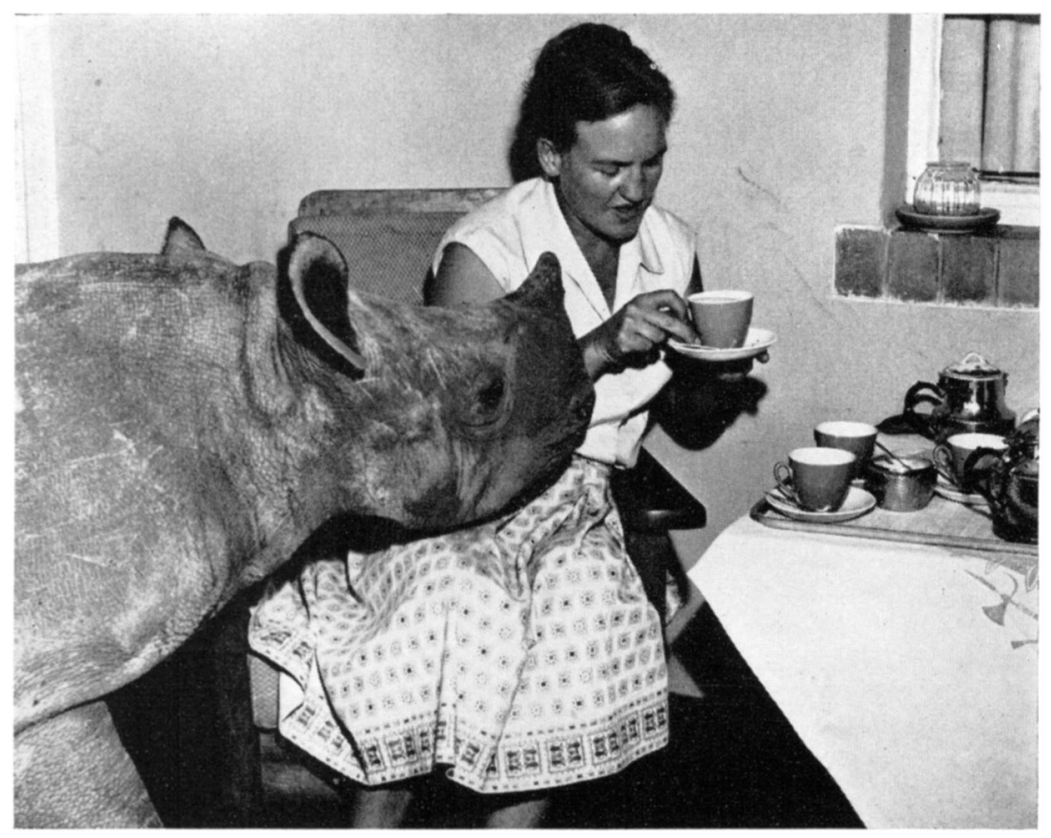

By courtesy of Rhodesia House.

RUPERT WITH HIS FOSTER-MOTHER, MRS. JOAN CONDY. OCTOBER, 1962. 


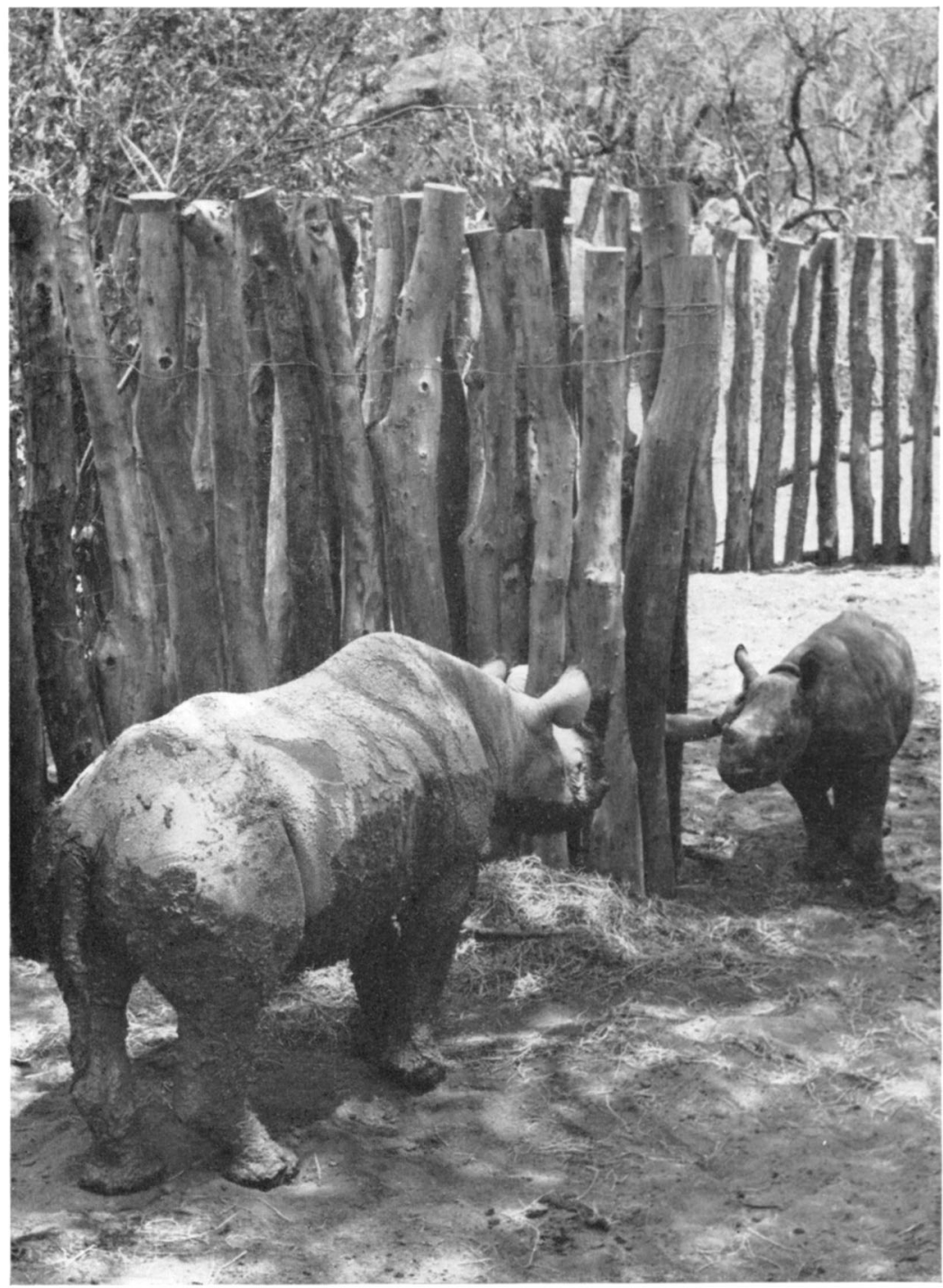

By courtesy of Rhodesia House.

RUPERT (RIGHT), 7 TO 8 MONTHS OLD, MEETS SAL. NOVEMBER, 1962. 
two-and-a-half months and by four months was eating cabbage, lucerne hay, and such things as locquat leaves. Later he developed a taste for a small wild combretum weed which grow in the grounds, and surprisingly enough, dried pine needles. His real passion however was bananas, which were used when required to lure him to a desired spot, or to lead him away when his presence was not required; although he would eat oranges, they could not be compared with bananas in Rupert's estimation. His long prehensile upper-lip developed rapidly after four months, and took the form of a small trunk. It was most interesting to see how he used it in browsing, and he was very fond of curling it round anyone's finger, which he would then proceed to suck with evident contentment.

Rupert's close association with the family dog, an Irish terrier named Ricky, led to some strange feeding habits. When Rupert began to eat lucerne hay, it was put into a box on the lawn and Ricky got into the way of eating from it, in addition to Rupert's bananas. Not to be outdone, Rupert would eat the mealie meal prepared for Ricky! It seemed at one stage that neither animal knew if it were dog or rhino.

Almost from the first Rupert was a real little rhino in every way; running up to full speed from a standing start; wheeling round on his hind legs like a polo pony; going down hindquarters first, then lying with his front feet tucked under him. The upward movement of his head, which could be painful to a visitor, made it advisable always to stroke or scratch him under the chin, not on the nose. When wallowing he rolled first on to one side then the other, never right over on to his spine. Rupert was wonderful with children-right from the start he was surrounded by them, and was treated with the scant respect they accord to all domestic animals. Starting with the four children at home, who throughout were quite without fear of him, he was ridden, pushed, slapped, teased, chased, and generally made to feel just one of the family.

From the middle of August, that is from the age of about four-and-a-half months, Rupert started to come indoors in the evenings, tapping at the french windows of the sitting room with his small horn, and when admitted wandering from chair to chair, until he got tired. Then he would flop down on the lion skin rug in the middle of the floor, and soon be asleep in blissful happiness. The problem now was to get him out of the house and over to his bed in the garage; to achieve this aim, his favourite bananas would often prove their worth. The T.V. set was a great attraction, and Rupert was often left for short periods with it as his sole companion, as he seemed to regard it as a human substitute. Humans he needed above all. When the family went out, leaving Rupert on his own, he would wander off in search of people, to the next door house, or if that was empty, to the next one, and so on. In October he acquired the bad habit of running after departing cars down the half-mile drive to the main road, and on several occasions wandered nearly a mile from home. The anxiety of his foster parents can be imagined with such a unique animal, completely devoid of road sense, loose on tarred roads in a semi-suburban area, but he came to no harm.

Rupert's moods varied enormously; at times he was lethargic, and only wanted to lie down and sleep; at others he would run at full speed round 
the large garden, make mock charges, and sometimes skip with all four feet off the ground like an enormous lamb. His wallowing routine started in September, and thereafter an area of bare earth was regularly flooded with a hose, to give him the mud he needed to cake himself with and cool off in the hot weather. Here again his action was identical with the grown animal - the sudden roll on to one side, up, then over on the other side-never right over, as it appears that a rhino's weight distribution prevents this. His only noise was a squeaking sound, rather like a puppy, used when hungry or needing company. Even when charging, there was no sign of the snorts and grunts emitted by the adult animal.

As his front horn grew, Rupert needed to scratch its base frequently, and what could be more convenient than under the bumper of the nearest car ? By the time he left, his front horn was 3 inches long, and his back horn a lump just starting to swell.

Right from his arrival, despite efforts to keep his presence a secret, Rupert started to attract a long list of guests, invited and uninvited. The Governor-General, with his family, all keen animal lovers, visited him twice. He was televised by the B.B.C. and Rhodesian T.V. Winford Vaughan Thomas, the famous commentator, on his way back from London to Australia, had heard all about Rupert, and the main thing he wanted to do in Salisbury was to see him. His taped commentary with Rupert's squeaking noises and bottle sucking, reached many British homes via the B.B.C., and was also broadcast in Australia. Rupert received regular mention, with photographs in the local newspapers, and this was extended all over Europe and even in the United States. The flow of visitors became so great that the gates had to be barred at week-ends to control the influx. Nearly everyone had a camera of some sort, and several artists visited this unusual sitter. Two Boy Scouts even came along during Bob-a-Job week to wash and scrub Rupert.

From the very start of his adoption, it had always been intended that Rupert should be returned to his wild state in due course. There had been many offers from zoos and circuses, some mentioning large sums of money, but of course there was never any question of such a fate for the little animal. It became increasingly obvious however by October, when Rupert was around six months old, that he would have to go. His wandering habits became more pronounced with the danger of collision with a passing car, and although his nature was really gentle, there was always the risk of him inadvertently hurting a child, for his strength was enormous.

So it was decided to move Rupert to the Matopos National Park, south of Bulawayo, there to join the two-year-old black rhino, Sal. She was being brought there at the same time from Wankie National Park, where she had been living since her rescue from Kariba in 1961. All who knew Rupert felt a great sorrow at the thought of losing him. So Sunday 4th November, 1962, was a sad day, with the National Parks Board truck, a wooden cage already in place on the body, backed up to the ramp ready for the traveller, and a sense of foreboding hanging in the air. Next morning, in front of a farewell party of journalists and press photographers, Rupert's bucket of milk was put into the truck, he followed it quietly in, the door was fastened, 
and his journey south of 300 miles started. He arrived that afternoon and was introduced to Sal the next morning.

Sal and Rupert are now inseparable in the Matopos National Park, and doing well. Sal is becoming somewhat of a menace, as she charges anyone coming near her on foot (not cars, fortunately). It would be interesting to know if this is her maternal instinct, to guard Rupert against any harm from the outside world. 